\title{
THE ROPY
}

HEALTH HAZARD EVALUATION REPORT 72-63-36

HAZARD EVALUATION SERVICES BRANCH

DIVISION OF TECHNICAL SERVICES

$\begin{array}{ll}\text { Establishment } \quad: & \begin{array}{l}\text { Ferry Morse Seed Company } \\ \text { Mountain View, California }\end{array}\end{array}$

Report Prepared By : Melvin T. Okawa, Project Officer

Regional Industrial Hygienist

Region IX, San Francisco, California

Arnold Bodner, M.D., Medical Officer Western Area Occupational Health Laboratory

Salt Lake City, Utah

Field Evaluation : Melvin T. Okawa

Arnold Bodner

Steven K. Shama, M.D., Medical Officer

Medical Services Branch

Cincinnati, Ohio

Laboratory AnaTyses: Russell Hendricks, Ph.D.

Western Area Occupational Health Laboratory

Originating Office : Jerome P. Flesch

Chief, Hazard Evaluation Services Branch

Cincinnati, Ohio

Apri1 1973

U.S. DEPARTMENT OF HEALTH, EDUCATION, AND WELFARE

NATIONAL INSTITUTE FOR OCCUPATIONAL SAFETY AND HEALTH

CINCINNATI, OHIO 45202 
U.S. DEPARTMENT OF HEALTH, EDUCATION, AND WELFARE

NATIONAL INSTITUTE FOR OCCUPATIONAL SAFETY AND HEALTH

CINCINNATI, OHIO 45202

HEALTH HAZARD EVALUATION REPORT 72-63

FERRY MORSE SEED COMPANY

MOUNTAIN VIEW, CALIFORNIA

APRIL 1973

I. SUMMARY DETERMINATION

Section 20(a)(6) of the Occupational Safety and Health Act of 1970, 29 U.S.C. $669(\mathrm{a})(6)$, authorizes the Secretary of Health, Education, and Welfare, following a written request by any employer or authorized representative of employees to determine whether any substance normally found in the place of employment has potentially toxic effects in such concentrations as used or found.

The National Institute for Occupational Safety and Health (NIOSH) received such a request from an authorized representative of employees regarding exposure to airborne dusts containing seed-treating chemicals or pesticides at the Ferry Morse Seed Company, Mountain View, California.

Seven compounds were judged to be of importance to this health hazard evaluation. Five have established occupational health standards as promulated by the U.S. Department of Labor (Federal Register, Part II, Vol. 37, №. 202, Tables G1 \& G2).

\section{Substances}

Thiram Aldrin - Skin **

Dieldrin - Skin

Gamma-Benzene Hexach7oride (Lindane) - Skin

Organo (alkyl) Mercury Compounds

Captan

Victoria Green
Federal Standard

$5.0 \mathrm{mg} / \mathrm{M}^{3}$
$0.25 \mathrm{mg} / \mathrm{M}^{3}$
$0.25 \mathrm{mg} / \mathrm{M}^{3}$
$0.5 \mathrm{mg} / \mathrm{M}^{3}$
$0.01 \mathrm{mg} / \mathrm{M}^{3}$
No Standard
No Standard

Occupational health standards are established at levels designed to protect workers occupationally exposed to a substance on a 8-hour per day, 40-hour per week basis over a normal working 7 ifetime.

\footnotetext{
* Units of measurement: $\mathrm{mg} / \mathrm{M}^{3}$ - mil7igrams of substance per cubic meter of air. ** Skin - Potential contribution to exposure by cutaneous absorption route.
} 
Page 2 - Health Hazard Evaluation Report 72-63

NIOSH investigators conducted environmental and medical investigations on August 2, September 19, November 14, 30 and December 1, 1972. Environmental data indicate that worker exposures to thiram, captan, aldrin, dieldrin, gamma- and beta-benzene hexachloride are not excessive based upon the latest research data reported in the 1iterature and the standards set for their safe use in industry. Eighteen (18) personal breathing zone samples were collected on representative workers in the plant. Sampling durations ranged from forty-five to one hundred and ten minutes. Thiram was found in only five of the samples, concentrations ranged from 0.2 to $7.60 \mathrm{mg} / \mathrm{M} 3$; four of these were collected in the Treating Room and one in the Packaging Room. Captan was detected in one of the eighteen samples at a concentration of $0.2 \mathrm{mg} / \mathrm{M} 3$. A7drin was found in seven of the eighteen samples and concentrations ranged from $0.1-0.5 \mu \mathrm{g} / \mathrm{M} 3$. Dieldrin was found in all eighteen samples; the concentrations ranged from $0.2-2.2 \mu \mathrm{g} / \mathrm{M} 3$. Gamma-benzene hexachloride was found in three samples; the concentrations ranged from $0.4-0.7 \mu \mathrm{g} / \mathrm{M} 3$. Final7y, beta-benzene hexachloride was found in twelve of the samples; the concentrations ranged from $0.1-1.5 \mu \mathrm{g} / \mathrm{M} 3$.

Mercury was not detected in any of the twenty-four blood samples drawn from workers throughout the plant. Red blood cell cholinesterase activity of these samples ranged from $0.64-0.91 \mathrm{\Delta pH} / \mathrm{hr}$ (normal values are between $0.55-1.25 \mathrm{\Delta pH} / \mathrm{hr}$ ). Dieldrin levels ranged from $0.0-8.3 \mathrm{ppb}$. Normal values have not been standardized; but the - levels fall within the "normal range" reported in the literature.

The most common reactions of workers to the dust from the materials being used at the plant were nonspecific upper respiratory irritation and contact dermatitis. Two cases of apparent thiram poisoning and one case of mercury poisoning have occurred in the past. No evidence of serious ilnness attributable to exposure to the subject substances was obtained during this evaluation.

On the basis of environmental and medical investigations conducted during the months of November and December as reported above it has been determined that the chemical agents (Thiram, A7drin, DieTdrin, Lindane, and Captan) are not toxic at the concentrations measured in this plant.

A1though the conditions evaluated at the time of our survey indicated no toxic effects, the potential for such could result in the future without improved housekeeping and improvement of 
Page 3 - Health Hazard Evaluation Report 72-63

ventilation control. Residual levels of dieldrin, aldrin, gammaand beta-benzene hexachloride remain in the plant even though the use of these materials has ceased. In addition, exposure to noise appeared excessive in the Mi11 and Packaging Rooms.

General recommendations to obviate potential1y toxic conditions have been made in the Fu11 Report.

Copies of the Summary Determination as well as the Full Report of the evaluation are available upon request from the Hazard Evaluation Services Branch, NIOSH, U.S. Post Office Building, Room 508, 5th and Wa7nut Streets, Cincinnati, Ohio 45202. Copies of both have been sent to:

a) Ferry Morse Seed Company, Mountain View, California

b) Authorized Representative of Employees

c) U.S. Department of Labor - Region IX

For purposes of informing the approximately 40 "affected employees," the employer wi11 promptly "post" the Summary Determination in a prominent place(s) near where affected employees work for a period of 30 calendar days. 
Page 4 - Health Hazard Evaluation Report 72-63

II. INTRODUCTION

Section 20(a)(6) of the 0ccupational Safety and Health Act of 1970 , 29 U.S.C. $669(a)(6)$, authorizes the Secretary of Health, Education, and Welfare, following a written request by any employer or authorized representative of employees, to determine whether any substance normally found in the place of employment has potentially toxic effects in such concentrations as used or found.

The National Institute for Occupational Safety and Health (NIOSH) received such a request from an authorized representative of employees regarding exposure to airborne dusts containing seed-treating chemicals or pesticides at the Ferry Morse Seed Company, Mountain View, California.

The Ferry Morse Seed Company is primarily a wholesale producer of chemically treated vegetable, grass, and flower seeds for use in agriculture and gardening. An estimated several million pounds of seeds are processed yearly in the plant by approximately 80 employees (40 in production and 40 in administration) during a single full shift.

III. BACKGROUND HAZARD INFORMATION

\section{A. Standards}

Seven compounds were judged to be of importance to this health hazard evaluation. Five have established occupational health standards as promulated by the U.S. Department of Labor (Federal Register, Part II, Vol. 37, No. 202, Tables GI \& G2).

Substances

Thiram

Aldrin - Skin **

Dieldrin - Skin

Gamma-Benzene Hexachloride (Lindane) - Skin

Organo (a ky 1 ) Mercury Compounds

Captan

Victoria Green

\section{Federal Standard}

$5.0 \mathrm{mg} / \mathrm{M}_{3}^{3}$ *

$0.25 \mathrm{mg} / \mathrm{M}_{3}^{3}$

$0.25 \mathrm{mg} / \mathrm{M}_{3}^{3}$

$0.5 \mathrm{mg} / \mathrm{M}_{3}^{3}$

$0.01 \mathrm{mg} / \mathrm{M}^{3}$

No Standard

No Standard

Occupational health standards are established at levels designed to protect workers occupationally exposed to a substance on a 8-hour per day, 40-hour per week basis over a normal working Tifetime.

* Units of measurement: $\mathrm{mg} / \mathrm{M}^{3}$ - mi11igrams of substance per cubic meter of air. Skin - Potential contribution to exposure by cutaneous absorption route. 
Page 5 - Health Hazard Evaluation Report 72-63

\section{B. Toxic Effects}

Two fungicides (Arasan and Orthocide 75) are used almost exclusively for treating vegetable and flower seeds at the Ferry Morse Plant. Grass seeds are generally treated with a mixture of brilliant areen (Victoria Green) and a dispersant. Other aqents have been used in the plant in the past, and the toxicity of these compounds will be discussed also.

Thiram (tetramethylthiuramdisulfide) is a fungicide which is a methyl analogue of Antabuse but is reportedly much more toxic. Thiram is known under various trade names, including Arasan, the one used at Ferry Morse. No systemic poisonings in man have been reported to date from thiram, but it is a moderately severe irritant of mucous membranes and a mild irritant of intact skin. In high oral doses, fatigue, sleepiness, headache, reduced potency, mild gastrointestinal disorders and minor confusion states have been occurred. A more severe effect from thiram exposure can occur when alcohol is ingested and can result in headache, vomiting, gastric pain, and diarrhea. For example, if a worker inhales sufficient quantities of thiram and also has an alcoholic beverage, the alcohol-thiram reaction may occur.

Aldrin $(1,2,3,4,10,10$-hexachloro-1 , 4,4a , 5,8,8a-hexahydro-1,4endo,-ex0-5,8-dimethanonaphthalene) is an insecticide of the cyclodiene group, a family of highly chlorinated cyclic hydrocarbons. Acute toxicity from aldrin is relatively high. It is absorbable via the gastrointestinal tract, inhalation, and throügh the skin (which constitutes the greatest occupational hazard). During acute exposures, aldrin appears to affect the central nervous system predominantly. The symptoms include hyperirritability, depression, headache, convulsions, vomiting, and nausea. Chronic exposure responses may be anorexia, loss of weight, headache, and nervousness. All of these symptoms are quite general and are not specific to aldrin alone. Some studies have been done on workers packaging and handling the material. The air conçentration of aldrin were determined to be between 1 and $2.6 \mathrm{mg} / \mathrm{M}^{3}$. No evidence of any adverse effects from this exposure was found. Aldrin is currently not in use at Ferry Morse.

Dieldrin (hexach1oro-epoxy octahydro-endo, exo-dimethanenapthalene) - is the epoxide of aldrin. Aldrin is converted to dieldrin in the body, and in a general way, dieldrin has the same physiological effects on humans. Dieldrin is absorbed readily through the skin, lungs, and the gastrointestinal tract. Early symptoms from acute exposure to the compound include headache, nausea, vomiting, and dizziness. In more severe cases, the principal site of action is the central nervous system. The dominant symptom being a series of 
Page 6 - Health Hazard Evaluation Report 72-63

convulsions, which may recur with increasing severity. This display of symptoms may be clinically indistinguishable from idiopathic epilepsy. Recovery usually occurs within 24 hours after exposure to the compound is terminated, and permanent effects from non-fatal contact in man have not been reported.

Benzene hexach7oride (hexach7orocyclohexane) is a mixture of stereoisomers and is a versatile insecticide: Like aldrin and dieldrin, this compound is no longer in use. The most effective isomer is the gamma, and this compound is available under the more common name, lindane. The primary response to gamma-benzene hexachloride is stimutation of the central nervous system resulting in hyperexcitability and convulsions. Some early acute symptoms include irritation of the eyes, nose, throat, and nausea and severe headache. The gamma isomer is highly purified and more toxic than the technical grade benzene hexachloride which is a mixture of five isomers (including betabenzene hexachloride). The response to the technical grade compound is similar to that of the gamma although the delta isomer tends to depress the central nervous system and counteracts the stimulating action of the ganma isomer. Histopathological changes seen with chronic exposure to these materials include such sites as the liver, kidneys, and lungs. However, these substances are considered, in general, not greatly hazardous to work with.

Captan ( $\mathrm{N}$-trichloromethylmercapto-4-cycilohexene-1,2-dicarboximide) is a fungicide of low toxicity. The lethal dose (LD50) is 9,000 to $15,000 \mathrm{mg} / \mathrm{kg}$ in rabbits. Chronic exposure of $1 \%$ in the diet of rats for two years produced no effect. At very high doses in animals, diarrhea and weight loss appear, but no tissue damage occurs. No human poisonings from captan have been reported to date. At Ferry Morse, captan is used under the trade name Orthocide 75.

Victoria Green is used as a fungicide or insecticide, and is known more commonty as brilliant green or malachite green. The toxicological data in the literature concerning human experience with the compound is extremely sparse. Most of the studies inyolve animals, and the LD50 for rabbits is $75 \mathrm{mg} / \mathrm{kg}$ (a much 7 ower lethal dose than for captan). In rabbits, toxic doses cause congestion and necrosis of the kidneys. For humans, brilliant green has been used in the past for medicinal purposes. Dilute formulations of the compound have been used topically for treatment of ring worms. It is not considered extremely hazardous to humans under normal working conditions, but may cause diarrhea and abdominal pain upon ingestion. 
Page 7 - Health Hazard Evaluation Report 72-63

Two organic mercury compounds have been used in the past at Ferry Morse. Panogen 15 and Ceresan M are trade names for methy 1 mercury dicyandiamide and ethy 1 mercury p-toluenesulfonilide respectively. Both of these chemicals are systemic poisons. While they are extremely toxic in terms of concentration needed to produce symptoms, they also are excreted slowly from the body. Most of the symptoms of toxicity are related to the central nervous system, such as tremor, hearing abnormalities, atoxia, personality changes, and weakness. Severe cases can include widespread degeneration of certain sensory nerve paths. There is no known accurate parameter for measuring mercury poisoning and diagnosis is a clinical one. However, blood levels, hair and nail content of mercury do have fairly good correlation with clinical symptoms.

Malathion (0,0-dimethyl dithiophosphate of diethyl mercapto succinate) is an organic phosphate insecticide with relatively low toxicity and low anticholinesterase potency. Common symptoms of cholinesterase poisoning are blurred vision, excessive salivation, sweating, nausea, vomiting, and diarrhea. Chronic toxicity can be evaluated by the level of enzyme cholinesterase in blood and comparing this value with that found before exposure. This compound is no longer in use at Ferry Morse.

IV. HEALTH HAZARD EVALUATION

A. Initial Visit - Observational Survey

An observational survey of the plant was conducted by Melvin T. Okawa, NIOSH industrial hygienist on August 2, 1972. Plant personnel involved in this walk-through survey inci lded :-

Plant Manager, pShop Steward (Teamsters Warehouse Loca7 \#655).

Plant Processes - Conditions of Use:

In the plant itself, raw seed is tested for germination and quality, sorted, treated with a combination of an antifungal agent and dye, and packaged for final distribution. The dye serves to discourage use of the seed in food preparation, an event which has occurred in underdeveloped countries and resulted in serious illness or death. 
Page 8 - Hea7th Hazard Evaluation Report 72-63

The initial steps in the processing of raw seed is conducted in the Mi11 Room. Approximately $6-8$ people work in this area, and they are responsible for operating a series of machines which are used to size and screen, separate, and clean the raw seed. No fungicides are used in this section of the plant, but at times, the machinery generates airborne dust. Four separate lines operate independently, and each piece of equipment is provided with a local exhaust system. However, processing of certain types of seed creates more dust than others. Noise may be a problem in this area, and ear protection for workers in this area is required by plant management.

The majority of raw seed is coated with fungicides and dyes in the Treating Room, which is a separate room located in the warehouse area of the plant. The Treating Room is separated from the warehouse by a sliding door, but in actuality, the door is kept open and the room is part of the warehouse. Two men are responsible for the operations in the Treating Room. One worker has the major responsibility of treating seeds, while the other one is in there part time to operate the bagging machine. From an elevated platform in one corner of the room, a worker dumps raw seed and the fungicide and dye combination into a seed tumbler. The seed tumbler is equipped with local exhaust ventilation, but is relatively ineffective because it does not enclose the seed tumbler in any manner. As the tumbler turns, dust escapes from the hatch cover which does not seal completely. A7so, a large window fan exhausts room air to the outside of the building. The greatest worker exposure to fungicides occurs in the Treating Room. Workers are provided with respirators, but rarely wear them for an entire shift. An added responsibility for the Treating Room operator is his job of weighing the fungicide and dye combination which is to be added to the raw seed. The scale is located on a bench outside of the room, and the worker reaches into a barrel of the compound and weighs the material. This sequence takes about 10 minutes to complete and is done several times a day depending on the seed orders. Potential exposure to fungicides was judged to be the occupational health hazard.

Some seed is treated outside of the Treating Room. In the warehouse, just outside of the room, grass seed is treated in Mistomatic or Panagen slurry machines. A Tiquid slurry of fungicide and dye is pumped into the elevated slurry machines which contain the raw seed. One worker is in charge of this operation. The compounds used in this area are, for the most part, Victoria Green and Orthocide 75 (captan). The area reportediy becomes dusty at times, but this condition was not observed during this investigator visits to the plant. Judging from the dye on the worker, the potential occupational health problem was noted to be low level exposure to Victoria Green and captan. 
Page 9 - Health Hazard Evaluation Report 72-63

A new operation for seed coating was also observed. The Seed Coating Room contains several "pans" which are actually revolving drums made of steel. The worker leans into the "pan" to monitor the coating operation. The "pans" have good local exhaust ventilation, and the workers are required to wear respirators. Two employees are involved, and no potential occupational health problems were noted.

Six employees work in the Packaging Room. Seed is added to the automatic Filling Machine. The "Filler" fills, weighs, and seals the cans of seed. Two persons monitor the machine. Further down the assembly line, three employees are responsible for the "Labeler," the "Caser," and the "Stitcher." These machines are the final steps in boxing the cans of seed for shipment. Also one fork7ift operator works in the Packaging Room. The greatest exposure to dust and chemicals occurs near the "Filler." Local exhaust ventilation is supplied and seems to be adequate, but it is reported that the area becomes fairly dusty at times. This condition was not observed during the visits to the plant. Careful maintenance of the existing ventilation may solve this problem. Each time a different seed is processed, the "Filler" has to be cleaned thoroughly to prevent cross contamination of different seed. The cleaning procedure entails "blowing down" the machine with a compressed air hose. It takes about $15-20$ minutes to complete this phase and is done several times a day. The worker wears a respirator during the cleaning, but does not wear protective clothing. Finally, employees near the "Filler" are exposed to possible high noise Tevels from vibrating cans, but this exposure is intermittent. Potential occupational health problems were judged to be low level exposure to fungicides and possible high noise.

The remainder of the plant is mostly warehouse and storage area. Jeep drivers and other employees in the warehouse get intermittent exposure to dust and chemicals whenever they handle bags of seed. There is one sweeper for the plant, but when it is in use, it seems to stir up as much dust as it vacuums. One sma17 grass seed bagging operation in the warehouse was also observed. Although dust levels did not seem excessive, there may be some low level exposure to Victoria Green.

As a result of this observational survey environmental samples for thiram, captan, and residues of other pesticides would be collected during the peak hearvest season (October-December). 
Page 10 - Health Hazard Evaluation Report 72-63

\section{B. Environmental Evaluation}

The Occupational Health Section of the Santa Clara County Hea7th Department had conducted two previous environmental and medical studies at the Ferry Morse plant (April and October of 1968). Environmental samples for lindane, dieldrin, captan, and thiram were collected with a hi-volume sampler for both general area and breathing zone samples. Concentrations of these compounds were found to be well below the federal standards for these fungicides during these surveys. During NIOSH's investigation, it was decided to concentrate on the two fungicides being used (thiram and captan). Residual levels of other pesticides could be assayed from the same samples.

On November 20 and December 1, 1972, personal breathing zone samples were collected with MSA Model $G$ battery powered vacuum pumps which were used to draw air through midget impingers containing 10 milliliters of ethylene glycol. The impingers were attached to the worker's lapel with special holders. The sampling rate was maintained at $1.6-1.7$ liters per minute and the sampling times ranged from 45 - 110 minutes in length. Workers were told to perform their jobs normal7y, and representative samples were collected.

The impinger liquid collecting medium (ethylene glycol) was transferred to a collection bottle which was sealed with a teflonlined bottle cap. The sample bottles were sent to NIOSH Taboratories in Salt Lake City, Utah, for analysis. There, it was decided to send the samples to a competent laboratory specifically doing pesticide analytical work. This decision was based upon the fact that NIOSH would have to spend time designing the analytical procedure when outside laboratories were already equipped for this type of work. In January of 1973, the samples were sent to Intermountain Laboratories, Salt Lake City, Utah.

Resu7ts:

Results are contained in Table I. Analys is for thiram and captan was done by the standard colormetric method used by the Association of Official Agricultural Chemists. ${ }^{18}$ The results were checked by a gas chromatograph method which is the standard one outlined by the Environmental Protection Agency (Perrine Primate Research Laboratories - Environmental Protection Agency, Perrine, Florida). Other peaks from the same graph used for thiram and captan levels were identified as aldrin, dieldrin, gamma-benzene hexachloride (1indane), and beta-benzene hexachloride. Thiram and captan levels are reported in milligrams per cubic meter $\left(\mathrm{mg} / \mathrm{M}^{3}\right)$ 
Page 11 - Health Hazard Evaluation Report 72-63

of air and the other compounds in micrograms per cubic meter $\left(\mu \mathrm{g} / \mathrm{M}^{3}\right)$ of air. One microgram equals $1 / 1000$ of a mi11igram.

Six breathing zone samples were collected on the primary worker in the Treating Room over a two-day period. Two samples were collected around the 10 minute weighing sequence that was discussed previously. The worker handles Arasan (thiram) directly. Four samples were taken which did not include the weighing sequence. of these, thiram was found in two of the samples (1.16 and 1.25 $\mathrm{mg} / \mathrm{M} 3)$. Thiram was found in both samples which included the 10minute weighing sequence $\left(1.56\right.$ and $\left.7.60 \mathrm{mg} / \mathrm{M}^{3}\right)$. The significance of these samples is that although the average level for thiram seems to be well below the 8-hour time-weighted standard, individual thiram concentration levels can make excursions above the standard concentration for the primary exposed worker in the Treating Room. Captan was not detected in any of the six samples. A trace of aldrin $\left(0.1 \mu \mathrm{g} / \mathrm{M}^{3}\right)$ was found in one sample; the standard is $250 \mu \mathrm{g} / \mathrm{M}^{3}$. Traces of dieldrin were found in a11 six samples $\left(0.2-0.6 \mu \mathrm{g} / \mathrm{M}^{3}\right)$; the standard is $250 \mu \mathrm{g} / \mathrm{M}^{3}$. Traces of gammabenzene hexachloride were found in three samples $\left(0.4-0.7 \mu \mathrm{g} / \mathrm{M}^{3}\right)$; the standard for 1 indane is $500 \mu \mathrm{g} / \mathrm{M} 3$ ). Finally, traces of betabenzene hexach7oride were found in three samples $\left(0.1-0.2 \mu \mathrm{g} / \mathrm{M}^{3}\right)$; there is no present standard for this compound.

Two personal breathing zone samples were collected on the worker in the Panagen area just outside of the Treating Room. Thiram was not detected and a trace amount of captan $\left(0.01 \mathrm{mg} / \mathrm{m}^{3}\right)$ was found in one sample. There is no present standard for.captan. Trace amounts of aldrin $(0.4 \mu \mathrm{g} / \mathrm{M} 3)$, dieldrin $(0.3$ and $1.6 \mu \mathrm{g} / \mathrm{M} 3)$, and beta-benzene hexachloride $\left(0.3-1.5 \mu \mathrm{g} / \mathrm{M}^{3}\right)$ were found in the two samples.

Breathing zone samples were collected on the workers in the Packaging Room. Three were collected on the Filling Machine operator. Thiram was found in one sample $\left(0.2 \mathrm{mg} / \mathrm{M}^{3}\right)$ and captan was not detected. Traces of aldrin were found in two samples $\left(0.1\right.$ and $\left.0.1 \mu \mathrm{g} / \mathrm{m}^{3}\right)$, traces of dieldrin in three $\left(0.4,1.3\right.$, and $\left.1.6 \mu \mathrm{g} / \mathrm{M}^{3}\right)$, and traces of beta-benzene hexachloride $(0.1,0.1$, and $0.1 \mu \mathrm{g} / \mathrm{M} 3$ ) were found in three samples. Four breathing zone samples were taken on the other workers in the Packaging Room. Thiram and captan were not detected. Traces of aldrin were found in two samples $\left(0.1\right.$ and $\left.0.3 \mu \mathrm{g} / \mathrm{M}^{3}\right)$, dieldrin in four $(0.2-1.0 \mu \mathrm{g} / \mathrm{M} 3)$, and beta-benzene hexach Toride in one $\left(0.1 \mu \mathrm{g} / \mathrm{M}^{3}\right)$. 
Page 12 - Health Hazard Evaluation Report 72-63

- Two samples were taken on a worker running the sweeper in the warehouse. Thiram and captan were not detected. A trace of aldrin was found in one sample $\left(0.5 \mu \mathrm{g} / \mathrm{M}^{3}\right)$ while traces of dieldrin $(0.4$ and 2.2 $\left.\mu \mathrm{g} / \mathrm{M}^{3}\right)$ and beta-benzene hexachloride $\left(0.1\right.$ and $\left.0.2 \mu \mathrm{g} / \mathrm{M}^{3}\right)$ were found in both. One sample was taken on the jeep driver in the warehouse. Only traces of dieldrin $(0.5 \mu \mathrm{g} / \mathrm{M} 3)$ and beta-benzene hexachloride $(0.2 \mu \mathrm{g} / \mathrm{M} 3)$ showed up in the sample.

Analysis of the data indicates that for most of the chemicals, only sma11 amounts of them became airborne. A trace amount of captan showed up in just a single sample out of 18 samples taken. Traces of chemicals whose use has been discontinued, however, did appear in several samples. in fact, traces of dieldrin, reportedly out of use for approximately one year, were found in all of the samples. The significance of this data is that pesticide residues can remain for long periods of time even after their use ceases, and reinforces the importance of good housekeeping when working with these toxic materials.

\section{Medical Evaluation}

The Ferry Morse Seed Company was visited by NIOSH physicians on two separate occasions. On September 19, 1972, Drs. Steven Shama and Arnold Bodner took part in an observation survey of the plant. Workers were interviewed to determine whether they had or were suffering any adverse effects from exposure to the materials being used in the plant.

The most common reactions of workers to the dust from materials used in the plant were nonspecific upper respiratory irritation and contact dermatitis. Several workers were aware that respirators and protective clothing were available, but almost all of them preferred not to wear them because of the inconvenience and discomfort. Two workers did report serious symptoms (frequent cramps, nausea, anorexia, headache, blurred vision) while working with thiram in the past. Also, one worker had been hospitalized for a short time reportedily due to acute exposure to Ceresan M (organic mercury compound).

On November 14, 1972, Dr. Arnold Bodner returned to the plant to draw blood samples from volunteer workers for subsequent analysis of red blood cell cholinesterase activity, mercury, and dieldrin levels.

Resu?ts (blood samples):

Twenty-four blood samples were drawn from workers at the Ferry Morse Seed Company plant. The majority of emp Toyees were involved in operations in the seed treating, packing, and warehouse areas of the plant. The results of the blood analysis are contained in Table II. 
Page 13 - Health Hazard Evaluation Report 72-63

The blood levels of mercury were done at NIOSH laboratories in Salt Lake City, Utah. The red cell cholinesterase levels were quantitated at the Solano Laboratories in Berkeley, California, and the dieldrin concentrations in blood were analyzed by Intermountain Laboratories in Salt Lake City, Utah. The mercury was analyzed by atomic absorption spectroscopy, the dieldrin by gas chromatography, and the cholinesterase by the method outlined in: Michel, H., Journal of Laboratory and Clinical Medicine, 34:1564 (1949).

Although, organic mercury compounds are no longer in use at the Ferry Morse plant, it was decided to look at the blood mercury level since it is a indicator of latent exposure due to the extremely slow rate of excretion of organic mercury from the body. According to references in the literature, normal blood levels of mercury are generally below 1.0 microgram $(\mu \mathrm{g})$ per 100 cubic centimeters $(\mathrm{cc})$ of blood. From Table II, it can be seen that mercury was not detected in any of the samples drawn from this population.

Red blood cell cholinesterase levels are reported in terms of activity. That is, the ratio of the change in the $\mathrm{pH}$ of the sample per hour of time $(\Delta \mathrm{pH} / \mathrm{Hr}$.). The normal ratio for cholinesterase in human blood is $0.55-7.25 .19$ It can be seen from Table II that all of the cholinesterase levels fall within normal limits.

Dieldrin levels are reported in parts per billion (ppb) in blood serum. A satisfactory method for measuring the absorption of dieldrin has not been developed, therefore, dieldrin poisoning is usual7y based on clinical symptoms and not laboratory tests. However, a few studies of dieldrin levels in blood have been published, and there seems to be fairly consistent data. In California, data from the Community Pesticide Project, ${ }^{17}$ non-occupationally exposed people shown no dieldrin levels in blood. In Florida, however, data from a study on non-occupationally exposed people showed a range of $2-390 \mathrm{ppb}$ of dieldrin in blood and farm workers averaged $200 \mathrm{ppb}$ of dieldrin in blood. ${ }^{17}$ Another study 16 showed that unexposed people had a range of $0.3-3.2$ ppb of dieldrin in blood, while workers exposed to "high," "medium," and "low" levels of dieldrin average $270,206,9.4 \mathrm{ppb}$ of dieldrin in blood respectively. The "high" exposure group had worked in the plant for eight years with no clinical signs of poisoning. At Ferry Morse, the highest dieldrin Tevel in blood was $8.3 \mathrm{ppb}$ with most workers exhibiting levels below $1.0 \mathrm{ppb}$. From employee interviews, it was found that no one exhibited clinical symptoms consistent with dieldrin poisoning. 
Page 14 - Hea7th Hazard Evaluation Report 72-63

\section{Conclusions}

- On the basis of environmental and medical investigations conducted during the months of November and December as reported above it has been determined that the chemical agents (Thiram, Aldrin, Dieldrin, Lindane, and Captan) are not toxic at the concentration measured in this pTant.

Although the conditions evaluated at the time of our survey indicated no toxic effects, the potential for such could result in the future without improved housekeeping and improvement of ventilation control. Residual levels of dieldrin, aldrin, gamma and beta-benzene hexachloride remain in the plant even though the use of these materials has ceased. Two cases of apparent thiram poisoning have occurred in the past and complaints of nonspecific dermatitis and upper airway irritation appear from time to time. In addition, exposure to noise appeared excessive in the Mil1 and Packaging Rooms. General recommendations are suggested in Section V to obviate potentially toxic conditions.

\section{RECOMMENDATIONS}

1. The existing local exhaust ventilation system in the Treating Room for the seed tumbler is inadequately designed and should be modified to provide more complete enclosure to be more effective. Seals on the hatch cover for the seed tumbler should be modified to prevent dust from escaping while the tumbler is rotating.

2. Al1 weighing of fungicides should be conducted in a hood.

3. A11 seed treating operations should be conducted in areas separate from open work sections of the plant and should have ventilation control.

4. A regular maintenance program for existing ventilation systems should be established.

5. More complete enclosure of existing operations which have ventilation control is recommended.

6. A concerted effort to improve housekeeping in the plant should be made. The sweeper should be used more regularly, but also should be serviced to insure that it is working properly. 
Page 15 - Health Hazard Evaluation Report 72-63

7. Protective clothing and approved respirators should be made readity available for those short-term operations that require their use. A regular maintenance program for respirators and protective clothing should be established.

8. Daily personal showering and regular laundering of clothing are recommended.

9. Employee exposures to noise should be evaluated and if necessary a stronger noise abatement program established and enforced.

10. In the event, that additional toxic compounds are to be used in the future, consideration for their effects on humans should be duly noted, and procedures for controlling their use instituted and enforced.

\section{REFERENCES}

1. Jalili, M.A., Abrasi, A.H., "Poisoning by Ethyl Mercury Toluene Sulphonilide, "Br. J. Ind. Med., 18:303-308, 1961.

2. Storrs, B., Thompson, J., et a1, "Epidemiologicat Notes and Reports. Organic Mercury Poisoning, Alamogordo, New Mexico," Morbid. Mortal. Weekly Rep., 19:25-26, 40, 1970.

3. Curley, A., Sedlak, V.A., et a1, "Organic Mercury Identified as the Cause of Poisoning in Humans and Hogs," Science, 172:65-67, 1971.

4. Ekman, L., Greetz, U., et a7, "Metabolism and Retention of Methyl Mescurie Nitrate in Man," Nor. Med., 79:450-456, 1968.

5. Takeuchi, T., "Biological Reactions and Pathological Changes in Human Beings and Animals Under the Condition of Organic Mercury Contamination." International Conference on Environmental Mercury Contamination, Ann Arbor, Michigan, 1970.

6. Tejning, S., "Mercury Contents in Blood Corpuscles, Blood Plasma, and Hair in Persons who had for Long Periods a High Consumption of Fresh Water Fish from Lake Vaner," Report 670831, Depart. of Occ. Med., Lund, Sweden, Univ. Hosp., 1967.

7. Gleason, Gosselin, and Hodge: Clinical Toxicology of Commercial Products (Baltimore, Md., 1963). 
Page 16 - Health Hazard Evaluation Report 72-63

8. Goldwater, L., Jacobs, M., Ladd, A., "Absorption and Excretion of Mercury in Man," Arch. of Env. Health, Vol. 6, pp. 480-483.

9. Goldwater et al: Vol 5, pp. 537-541.

10. Ibid, Vo1. 9, pp. 454-463.

11. Gage, J.D., "Distribution and Excretion of Methy1 and Pheny? Mercury Salts," British J. of Ind. Med., 21:197, 1964.

12. Joselin, M., Lourie, D., Browder, A., "Mercurialism; Environmental and Occupational Aspects, "Annals of Internal Medicine, 76:119, 1972.

-13. Conley, B.E., A Review: Occupational Dieldrin Poisoning, J. Am. Med. Assoc., 172:2077-2080, 1960.

14. Negherbon, W.0., A Compendium: Handbook of Toxicology, Volume III: Insecticides, W.B. Saunders Co., Philadelphia, 1959.

15. Patty, F.A., Ed., Industrial Hygiene and Toxicology. Volume II, Interscience Pubiishers, 1963, pp. 1356-1358.

16. Da7e, et al, "Hexane Extractable Chlorinated Insecticides in Blood," Life Science, 5:47-54, 1966.

17. Personal Communication with Dr. Alice Ottaboni, Food and Drug Div., California State Department of Public Health, March 20, 1973.

18. Horwitz, William, Official Methods of Analysis of the Association of Agricultural Chemists, 10th Edition, page 410, 1965, A.0.A.C., Washington, D.C.

19. Michel, H., An Electric Method for the Determination of Red Blood Cell and Plasma Cholinesterase Activity. Journal of Laboratory and Clinical Medicine. Volume 34, pp. 1564-1568, 1949; and Current Interpretation of Normat Ranges of Cholinesterase Activity by Solano Laboratories, Inc., Berkeley, California. 


\begin{tabular}{|c|c|c|c|c|c|c|c|c|}
\hline Sample \# & Area/Occupation & $\begin{array}{l}\text { Sample Time } \\
\text { (minutes) }\end{array}$ & $\begin{array}{l}\text { Thi ram } \\
\left(\mathrm{mg} / \mathrm{M}^{3}\right)^{*}\end{array}$ & $\begin{array}{l}\text { Captan } \\
\left(\mathrm{mg} / \mathrm{M}^{3}\right)\end{array}$ & $\begin{array}{l}\text { Aldrin } \\
\left(\text { ug/M } M^{3}\right) *\end{array}$ & $\begin{array}{l}\text { Dieldrin } \\
\left(\mathrm{ug} / \mathrm{M}^{3}\right)^{2}\end{array}$ & $\begin{array}{c}\mathrm{G}-\mathrm{BHC} \\
\left(\mathrm{ug} / \mathrm{M}^{3}\right) \\
\end{array}$ & $\begin{array}{r}\mathrm{B}-\mathrm{BHC} \\
\left(\mathrm{ug} / \mathrm{M}^{3}\right) \\
\end{array}$ \\
\hline $\begin{array}{r}2 \\
6 \\
8 \\
10 \\
15 \\
17\end{array}$ & $\begin{array}{cl}\text { Treating Rm (operator) } \\
\text { " } \\
" 1 \\
" 1 \\
\text { " "(weighing) }\end{array}$ & $\begin{array}{r}110 \\
48 \\
52 \\
70 \\
89 \\
45\end{array}$ & $\begin{array}{l}\text { 1.25 } \\
\text { N.D. } \\
\text { N.D. } \\
1.16 \\
7.60 \\
1.56\end{array}$ & $\begin{array}{l}\text { N.D. *ћ } \\
\text { N.D. } \\
\text { N.D. } \\
\text { N.D. } \\
\text { N.D. } \\
\text { N.D. }\end{array}$ & $\begin{array}{l}\text { O.1 } \\
\text { N.D. } \\
\text { N.D. } \\
\text { N.D. } \\
\text { N.D. } \\
\text { N.D. }\end{array}$ & $\begin{array}{l}0.4 \\
0.6 \\
0.2 \\
0.2 \\
0.3 \\
0.2\end{array}$ & $\begin{array}{l}\text { N.D. } \\
\text { N.D. } \\
0.4 \\
0.4 \\
\text { N.D. } \\
0.7\end{array}$ & $\begin{array}{l}0.1 \\
0.2 \\
\text { N.D. } \\
\text { N.D. } \\
\text { O.2 } \\
\text { N.D. }\end{array}$ \\
\hline $\begin{array}{l}4 \\
5\end{array}$ & $\underset{11}{\text { Treating Area (panagen) }}$ & $\begin{array}{l}65 \\
85\end{array}$ & $\begin{array}{l}\text { N.D. } \\
\text { N.D. }\end{array}$ & $\begin{array}{l}\text { N.D. } \\
0.01\end{array}$ & & $\begin{array}{l}0.3 \\
1.6\end{array}$ & $\begin{array}{l}\text { N.D. } \\
\text { N.D. }\end{array}$ & $\begin{array}{l}1.5 \\
0.3\end{array}$ \\
\hline $\begin{array}{r}7 \\
11 \\
16 \\
12 \\
3 \\
18 \\
14\end{array}$ & $\begin{array}{c}\text { Packaging (filler op.) } \\
\text { " } \\
\text { " (blowing down) } \\
\text { " (jeep driver) } \\
\text { "( (labeler) }\end{array}$ & $\begin{array}{l}94 \\
73 \\
56 \\
70 \\
99 \\
94 \\
73\end{array}$ & $\begin{array}{l}0.2 \\
\text { N.D. } \\
\text { N.D. } \\
\text { N.D. } \\
\text { N.D. } \\
\text { N.D. } \\
\text { N.D. }\end{array}$ & $\begin{array}{l}\text { N.D. } \\
\text { N.D. } \\
\text { N.D. } \\
\text { N.D. } \\
\text { N.D. } \\
\text { N.D. } \\
\text { N.D. }\end{array}$ & $\begin{array}{l}0.1 \\
\text { N.D. } \\
0.7 \\
\text { N.D. } \\
\text { N.D. } \\
0.1 \\
0.3\end{array}$ & $\begin{array}{l}0.4 \\
1.6 \\
1.3 \\
0.2 \\
0.3 \\
0.2 \\
1.0\end{array}$ & $\begin{array}{l}\text { N.D. } \\
\text { N.D, } \\
\text { N.D. } \\
\text { N.D. } \\
\text { N.D. } \\
\text { N.D. } \\
\text { N.D. }\end{array}$ & $\begin{array}{l}0.1 \\
0.7 \\
0.1 \\
\text { N.D. } \\
\text { N.D. } \\
0.1 \\
\text { N.D. }\end{array}$ \\
\hline $\begin{array}{r}7 \\
19 \\
9\end{array}$ & $\begin{array}{c}\text { Warehouse (sweeper) } \\
\text { " } \\
\text { " (jeep driver) }\end{array}$ & $\begin{array}{l}60 \\
45 \\
68\end{array}$ & $\begin{array}{l}\text { N.D. } \\
\text { N.D. } \\
\text { N.D. }\end{array}$ & $\begin{array}{l}\text { N.D. } \\
\text { N.D. } \\
\text { N.D. }\end{array}$ & $\begin{array}{l}\text { N.D. } \\
0.5 \\
\text { N.D. }\end{array}$ & $\begin{array}{l}0.4 \\
2.2 \\
0.5\end{array}$ & $\begin{array}{l}\text { N.D. } \\
\text { N.D. } \\
\text { N.D. }\end{array}$ & $\begin{array}{l}0.1 \\
0.2 \\
0.2\end{array}$ \\
\hline
\end{tabular}

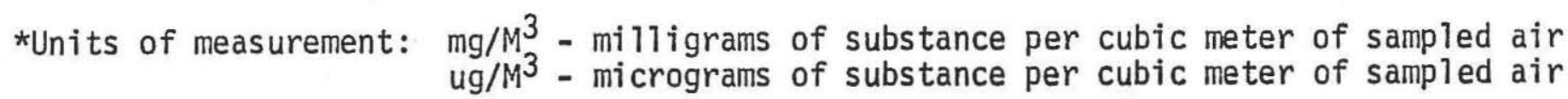

**N.D. - not detected in the sample: Sensitivity of Analytical Methods

$\begin{array}{ll}\text { Thiram } & -1 \mathrm{ppm} \text { (parts per million) } \\ \text { Captan } & -5 \mathrm{ppb} \text { (parts per bilition) } \\ \text { Aldrin } & -1 \mathrm{ppb} \\ \text { Dieldrin } & -7 \mathrm{ppb} \\ \text { G-BHC, B-BHC } & -1 \mathrm{ppb}\end{array}$




\section{Mercury (ug/100 cc of blood)** RBC Cholinesterase $(\Delta \mathrm{pH} / \mathrm{Hr} .)^{\star \star \star \star}$}

Dieldrin

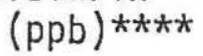

\section{E. R.}

T. B.

R. S.

H. S.

A. H.

V. A.

E. B.

M. P.

G. C.

A. S.

B. W.

W. J.

M. S.

J. C.

J. 0 .

B. G.

V. S.

M. R.

E. S.

T. M.

M. A.

J. $S$.

J. $P$.

A. G.

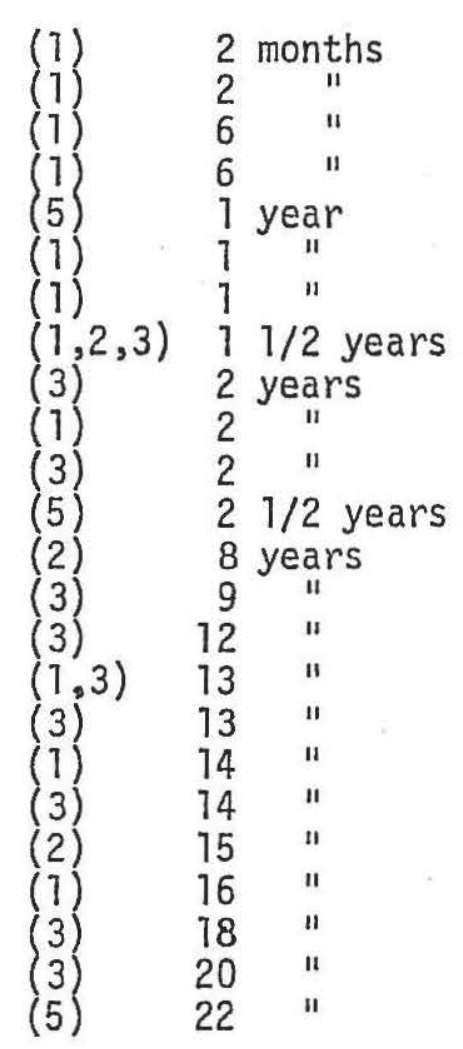

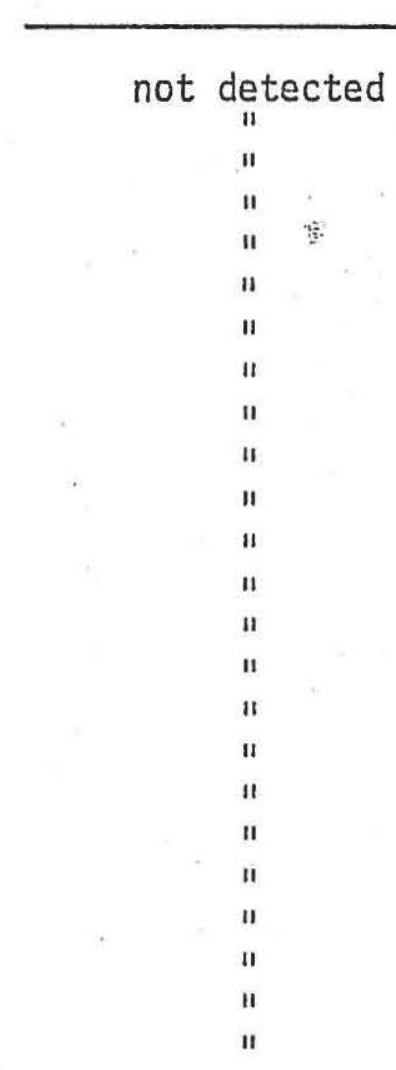

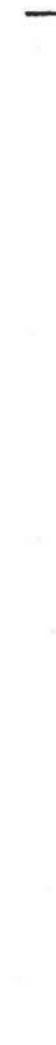

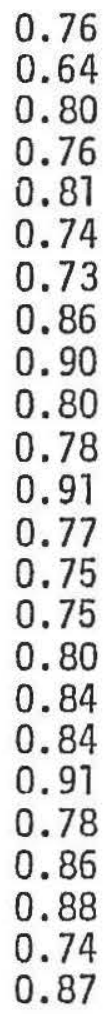

0.4

0.4

0.3

0.2

0.4

0.4

0.2

0.4

0.4

0.6

0.2

0.2

0.6

0.2

0.0

0.6

0.9

8.3

1.1

1.3

0.6

0.4

0.3

0.4

* Job code - (1) seed treating (2) packing (3) warehouse (4) sorting (5) other e.g. maintenance, etc. **ug/100 cc - micrograms of mercury per $100 \mathrm{cc}$ of blood (normal $11.0 \mathrm{ug} / 100 \mathrm{cc}$ )

*** $\Delta \mathrm{pH} / \mathrm{Hr}$. - cholinesterase activity (normal 0.55 - 1.25)

$* * * *$ Unit of measurement - ppb: parts per billion by weight 